Original Research Paper

\title{
Mode of Action Anti Serangga dari Tananam Jayanti (Sesbania sesban L. Merr.)(MAGNOLIOPSIDA: FABACEAE)
}

\author{
Suripto $^{1 *}$, Tresnani, G. ${ }^{2}$, Gunawan, E. R. ${ }^{3}$ \\ ${ }^{1}$ Anggota Kelompok Riset Ekologi, FMIPA Universitas Mataram \\ ${ }^{2}$ Anggota Kelompok Riset Fisiologi Hewan, FMIPA Universitas Mataram \\ ${ }^{3}$ Anggota Kelompok Riset Kmia Analitik, FMIPA Universitas Mataram
}

\author{
Riwayat artikel \\ Received : 07 Mei 2020 \\ Revised : 10 Mei 2020 \\ Accepted : 19 Mei 2020 \\ Published : 25 Mei 2020 \\ *Corresponding Author: \\ Suripto, \\ Biology Study Program Faculty \\ of Mathematics and Natural \\ Sciences, University of \\ Mataram, Indonesia; \\ Email: $\underline{\text { suriptobio@unram.ac.id }}$
}

\begin{abstract}
Abstrak: Dari hasil penelitian-penelitian sebelumnya telah diketahui, bahwa tanaman Jayanti (Sesbania. Sesban) memiliki aktivitas anti serangga terhadap Plutella xylostella, salah satu jenis serangga hama penting tanaman kubis. Juga telah diketahui, bahwa bahan aktif anti serangga dari S. sesban dengan konsentrasi tertentu dapat mematikan imago Diadegma semiclausum, yang merupakan musuh alami dari P. xylostella. Namun demikian, mode-mode aksi aplikasi bahan insektisida dari $S$. sesban yang selektif untuk pengendalian serangga hama, yaitu dapat menekan populasi $P$. xylostella namun aman terhadap populasi $D$. semiclausum belum diketahui. Penelitian ini bertujuan untuk mengetahui mode-mode aksi aplikasi berbagai fraaksi ekstrak daun $S$. sesban yang selektif untuk pengendalian $P$. xylostella. Serbuk kering daun $S$. sesban diekstraksi secara bertingkat menggunakan seri pelarut, yaitu berturut-turut petroleum eter, diklorometana, etanol dan air. Masing-masing fraksi ekstrak daun $S$. sesban dilakukan bioassay terhadap $P$. Xylostella secara parallel, yaitu uji mortalitas larva, uji daya tolak ovipositor, uji penghambatan penetasan telur dan uji anti feedant. Data hasil setiap uji hayati diolah dengan analisis probit untuk menentukan $\mathrm{LC}_{50}$ (mortalitas larva) dan $\mathrm{EC}_{50}$ (daya tolak ovipositor, penghambatan tetas telur dan daya anti feedant). Hasil menunjukkan, bahwa fraksi ekstrak-etanol daun $S$. sesban memiliki daya anti serangga terhadap $P$. xylostella lebih tinggi daripada fraksi-fraksi ekstrak lainnya. Hasil juga menunjukkan, bahwa aplikasi fraksi ekstrak-etanol daun $S$. sesban melalui mode-mode aksi anti ovipositor dan anti feedant adalah selektif untuk pengendalian P. xylostella. Harga $\mathrm{EC}_{50}$ daya tolak ovipositor $(20.52 \mathrm{ppm})$ dan $\mathrm{EC}_{50}$ anti feedant $(26.77 \mathrm{ppm})$ terhadap $P$. xylostella masing-masing lebih kecil daripada harga $\mathrm{LC}_{50}(37.38 \mathrm{ppm})$ terhadap $D$. semiclausum. Disarankan, bahwa penggunaan ekstrak daun S. sesban untuk pengendalian $P$. xylostella hendaknya diarahkan untuk aplikasi menolak oviposisi dan menghambat aktivitas makan dan tidak disarakan untuk aplikasi mematikan larva dan menghambat penetasan telur $P$. xylostella. Juga disarankan, bahwa selektivitas ekologis dan efektivitas pengendalian $P$. xylostella dengan insektisida dari S. sesban perlu dievaluasi dengan mempelajari lebih lanjut stabilitas anti serangga dari $S$. sesban selama penyimpanan serbuk kering daun sebelum diekstraksi, penyimpanan ekstrak sebelum diaplikasikan, dan stabilitasnya selama aplikasi.
\end{abstract}

Kata kunci: Diadgma semiclausum, mode aksi anti serangga, Plutella xylostella, Sesbania sesban.

Abstract: From the results of previous studies have been known that Jayanti (Sesbania sesban) plants have anti-insect activity against Plutella xylostella, one of the important species of insect pests of cabbage. It is also well known, that the antiinsect active ingredient from $S$. sesban with a certain concentration can kill Diadegma semiclausum imago, which is a natural enemy of $P$. xylostella. However, selective modes of action for the application of insecticides from $S$. sesban for pest control, which suppress $P$. xylostella populations but are safe against $D$. semiclausum are not yet known. The $S$. sesban leaf dry powder was extracted stratified using a series of solvents, namely petroleum ether, dichloromethane, ethanol and water, respectively. Each fraction of S. sesban leaf extract was bioassayed on P. xylostella in parallel, 
namely larval mortality, ovipositor resistance, egg hatching inhibition and antifeedant tests. Data on the results of each bioassay was analyzed by probit analysis to determine $\mathrm{LC}_{50}$ (larval mortality) and $\mathrm{EC}_{50}$ (ovipositor resistance, egg hatching inhibition and anti-feedant power. The results show that the extract fraction-ethanol of $S$. sesban leaves has higher insect repellent ability against $P$. xylostella than other extract fractions. The results also showed that the application of $S$. sesban leaf extract fraction-ethanol through each mode of action of anti-ovipositor and anti-feedant was selective for the control of $P$. xylostella. Each of the reject ovipositor $\mathrm{EC}_{50}(20.52$ ppm) and anti-feedant $\mathrm{EC}_{50}(26.77 \mathrm{ppm})$ values against $P$. xylostella was smaller than the $\mathrm{LC}_{50}$ price $(37.38 \mathrm{ppm})$ against $D$. semiclausum imago. It is recommended that the use of $S$. sesban leaf extract for controlling $P$. xylostella should be directed with application to reject oviposition and inhibit eating activities. This is because the concentration of the extract application is safe against D. semiclausum. Application of $S$. sesban leaf extract is not recommended to kill larvae and inhibit hatching eggs of $P$. xylostella because it requires a greater concentration of extract application and can suppress the population of $D$. semiclausum. Ecological anti-insect selectivity and effectiveness of using insecticide from $S$. sesban for the control of $P$. xylostella need to be evaluated by further studying the stability of the anti-insect active ingredient from $S$. sesban during storage of dried leaf powder before extracting, storage of extracts before being applied, and their stability during application.

Keywords: Diadegma semiclausum, insecticidal mode of action, Plutella xylostella, Sesbania sesban.

\section{Pendahuluan}

Sebagai penghasil vitamin dan mineral, sayuran merupakan salah satu sumber gizi yang dibutuhkan bagi tubuh. Sayuran yang banyak dikonsumsi masyarakat diantaranya adalah kubis daun (Brassica oleracea var capitata L.), kubis bunga (Brassica oleracea var botrytis L.) dan sawi putih (Brassica pekinensis Lour.). Produksi sayuran kubis di Indonesia masih tergolong rendah, baik kuantitas maupun kualitasnya. Salah satu faktor penyebab rendahnya produksi sayuran di Indonesia adalah akibat serangan hama dan penyakit. Ada dua jenis hama penting yang menyerang tanaman Cruciferae yaitu $P$. xylostella dan Crocidolomia binotalis Zell. Akibat serangan hama $P$. xylostella menyebabkan produksinya menurun sampai lebih dari 90 persen (Anil et al., 2013).

Penggunaan insektisida untuk pengendalian hama tersebut di dunia lebih dari 1 milyar US\$ per tahunnya (Solichah et al., 2014). Namun demikian, praktek pengendalian hama dengan menggunakan insektisida secara berlebihan menimbulkan beberapa masalah, antara lain resurjensi dan resistensi hama, letusan hama ke dua, dan menurunnya populasi parasitoid sebagai agen pengendali alami terhadap serangga hama.

Untuk menekan timbulnya masalah lingkungan dalam pengendalian serangga hama tersebut, maka perlu dicari alternatif penggunaan insektisida alami yang dapat mengendalikan hama secara efektif. Jayanti (S. sesban) merupakan salah satu jenis tumbuhan tropis yang telah diketahui memiliki potensi anti serangga. Namun demikian, golongan senyawa mana yang aktif anti serangga dari daun $S$. sesban, spektrum efek toksik, mode of action anti serangga dan stabilitasnya belum diketahui. Dengan demikian, suatu penelitian perlu dilakukan dengan masalah yang menjadi perhatian utama adalah "Bagaimana mode of action anti serangga dari tanaman $S$. sesban tersebut?" Mode of action anti serangga yang dipelajari dalam penelitian ini adalah meliputi daya larvasida, daya anti ovipositor, dan daya anti feedan dari fraksi ekstrak etanol daun jayanti ( $S$. sesban) terhadap serangga hama kubis (P. xilostella)

\section{Bahan dan Metode}

\section{Ekstraksi Senyawa Aktif Anti Serangga dari Daun $S$. sesban}

Tanaman jayanti ( $S$. sesban) dipilih sebagai tanaman sumber insektisida alami, yang didasarkan atas pertimbangan-pertimbangan berikut ini:

1) Tanaman jayanti memiliki banyak ciri yang cocok dengan karakteristika dasar seleksi tumbuhan untuk sumber insektisida alami, seperti yang dikemukakan oleh Hamburger \& Hostettmann (2011), antara lain yaitu tanaman diketahui memiliki potensi anti serangga, tanaman tersedia secara lokal, mudah tumbuh atau dibudidayakan oleh petani, dan bahan aktif dapat ditarik dengan peralatan dan teknologi yang sederhana.

2) Bahan aktif insektisida dari tanaman jayanti berasal dari golongan senyawa saponin. Golongan senyawa ini bersifat polar, mudah larut dengan air sehingga cara penarikan dan aplikasinya "feasible" bagi petani. 
Selain dari pada itu, golongan senyawa tersebut mudah mengalami degradasi setelah aplikasi sehingga pemakaian bahan insektisida alami ini bersifat aman lingkungan.

Identifikasi jenis tanaman jayanti (S. sesban) di lapangan dilakukan dengan menggunakan buku kunci determinasi dari Backer \& van den Brink (1965 dalam Suripto et al., 2017). Tanaman yang sudah dideterminasi sebagai jenis S. sesban dikoleksi daunnya (dari tanaman yang sudah berumur dua tahun atau lebih dengan indikasi tanaman tersebut sudah berbuah, di mana tanaman sudah dapat memproduksi senyawa metabolit sekunder, termasuk golongan saponin). Setelah "dikeringanginkan", daun S. sesban digiling, dan serbuk kering daun (simplisia) yang dihasilkan ditarik kandungan aktif anti serangganya dengan menggunakan teknik diekstraksi cair-padat secara bertingkat dengan menggunakan seri pelarut, yang kepolarannya meningkat, yaitu berturutturut petroleum eter (PE), diklorometan (DCM), etanol $(\mathrm{EtOH})$ dan air.

Pemilihan pelarut berdasarkan tingkat kepolarannya ini bertujuan untuk melarutkan semua golongan senyawa aktif dari daun S. sesban sesuai dengan kepolarannya. Masing-masing tingkat ekstraksi dilakukan dengan menggunakan teknik maserasi serbuk kering (simplisia) daun jayanti sesuai dengan prosedur yang dikembangkan Suripto et al. (2017). Ekstrak murni masing-masing fraksi diperoleh dengan cara menguapkan pelarut pada tingkat ekstraksi yang bersangkutan, dengan menggunakan penguap putar vakum (vacuum rotary evaporator) dan setelah dipindahkan ke dalam cawan, ekstrak kental yang dihasilkan dikesatkan lebih lanjut dengan menggunakan teknik pemekatan ekstrak di ruang penguapan.

Ekstrak murni (dalam bentuk pasta) yang dihasilkan dimasukkan ke dalam botol gelap dan siap untuk digunakan dalam uji hayati. Bagan alir kerja ekstraksi cair-padat daun $S$. sesban secara bertingkat ini dapat dilihat pada Gambar 1.

Sebelum digunakan untuk uji hayati, masingmasing fraksi ekstrak daun $S$. sesban yang dihasilkan diperiksa kandungan saponinnya menggunakan teknik uji busa dan kromatografi lapis tipis (KLT), menurut metode yang dikembangkan Harborne (1987 dalam Suripto et al., 2017). yang menggunakan pelat silika gel G/uv $254 \mathrm{~nm}$ sebagai fase diam dengan sistem pengembang satu arah. Pada KLT yang menggunakan fase pengembang heksanEtOAc (1:1) dan dengan penampak bercak $\mathrm{CHCl}_{3}$, sampel yang memperlihatkan bercak dengan warna kuning dan coklat merah menandai adanya golongan senyawa saponin. KLT juga dilakukan dengan menggunakan pengembang ButOH- $\mathrm{H}_{2} \mathrm{O}(1: 1)$, yang akan menghasilkan serapan di bawah ₹ $254 \mathrm{~nm}$, untuk membandingkan bilangan rf setiap sampel ekstrak dengan saponin strandar.

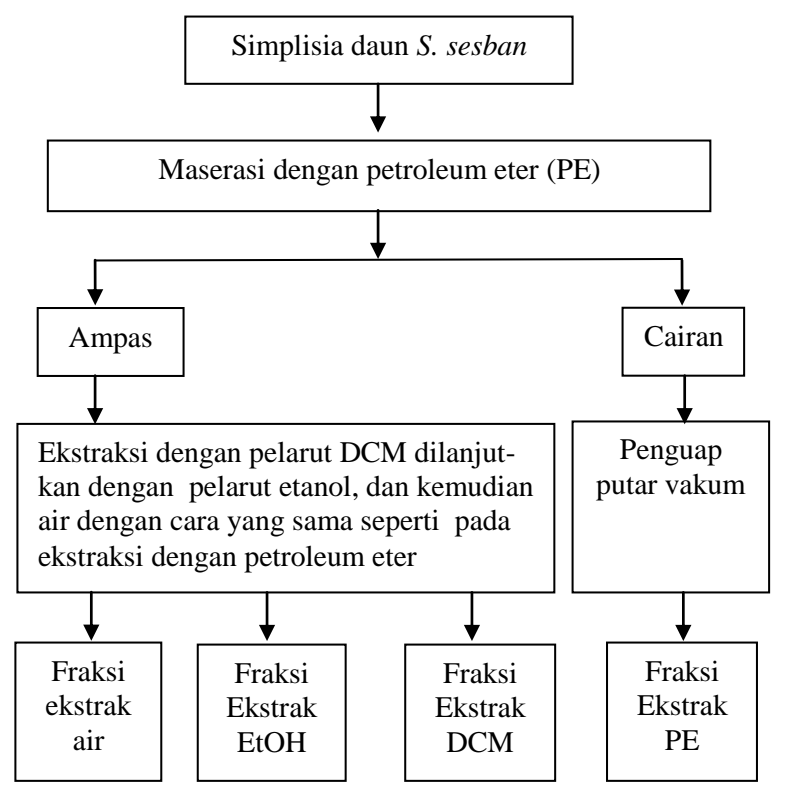

Gambar 1. Bagan alir kerja ekstraksi cair-padat daun S. sesban secara bertingkat.

\section{Perbanyakan $P$.xylostella}

Pupa dari P. xylostella dikoleksi di perkebunan kubis Sembalun Lombok Timur. Pembiakan (rearing) massal $P$. xylostella menggunakan daun kubis sebagai pakan dan tanaman kubis umur 15-20 hari sebagai tempat untuk uji hayati in situ. Rearing dilakukan menurut prosedur dari Solichah et al. (2014) dan Wang \& Keller (2018) hingga dihasilkan tahapan telur, larva (instar III), dan imago untuk masing-masing uji hayati.

\section{Uji Hayati}

Sebelum uji-uji hayati utama (definitive bioassays), terlebih dahulu dilakukan uji pendahuluan (prelimanary screening) toksisitas letal masing-masing fraksi ekstrak daun $S$. sesban terhadap larva $P$. xylostella dengan prosedur standar dari APHA (Clesceri et al., 1989), dan dimodifikasi oleh Suripto et al. (2017) guna menentukan konsentrasi aplikasi (6 taraf konsentrasi, termasuk kontrol) untuk uji-uji hayati utama, yang meliputi uji daya tolak ovipositor, uji daya ovisida, uji mortalitas larva, dan uji daya anti feedan masing-masing fraksi ekstrak daun $S$. sesban terhadap $P$. xylostella. Masing-masing unit uji hayati dilakukan secara in situ di perkebunan kubis Sembalun Kabupaten Lombok Timur menurut rancangan acak lengkap dengan menggunakan empat ulangan untuk setiap perlakuan konsentrasi. Untuk menghindari bias, uji hayati dilaksanakan pada kondisi siang hari yang cerah.

Uji mortalitas larva $P$. xylostella dilakukan terhadap 10 larva instar III per tanaman kubis. Perlakuan 
diberikan dengan cara menyemprotkan larutan ekstrak pada permukaan daun kubis terinfeksi larva. Variabel yang diamati adalah prosentase jumlah larva yang mati setiap tiga jam selama 24 jam setelah perlakuan.

Uji daya tolak ovipositor dilakukan pada tanaman kubis. Perlakuaan diberikan dengan cara menyemprotkan $10 \mathrm{ml}$ larutan ekstrak pertanaman kubis secara merata sebelum didedahkan dari populasi imago betina $P$. xylostella. Variabel yang diamati adalah jumlah telur $P$. xyostella per tanaman kubis selama 3 x 24 jam setelah perlakuan. Prosentase penghambatan oviposisi dihitung berdasarkan selisih antara rerata jumlah telur per tanaman kubis pada perlakuan konsentrasi tertentu dengan rerata jumah telur per tanaman kubis pada perlakuan kontrol.

Uji daya anti feedan dilakukan terhadap 10 larva $P$. xylostlla yang diinfeksikan pada tiap tanaman kubis. Perlakuan diberikan dengan menyemprotkan larutan ekstrak pada tanaman kubis sebelum diinfeksikan larva. Variabel yang diamati adalah volume daun kubis yang dimakan oleh larva selama 3 x 24 jam perlakuan. Prosentase daya anti feedan dihitung berdasarkan selisih rerata volume daun kubis yang dimakan larva pada perlakuan konsentrasi tertentu dengan rerata volume daun kubis yang dimakan larva pada perlakuan kontrol.

Uji daya ovisidal juga dilakukan secara terhadap rumpun telur $P$. xylostella pada tanaman kubis. Perlakuaan diberikan dengan menyemprotkan $10 \mathrm{ml}$ larutan ekstrak secara merata per tanaman kubis yang terinfeksi telur. Variabel yang diamati adalah prosentase jumlah telur yang tidak menetas menjadi larva per tanaman kubis selama 3 x 24 jam setelah perlakuan.

Bagan alir kerja uji hayati anti serangga dari tanaman S. sesban terhadap P. xylostella ini dapat dilihat pada Gambar 2.

\section{Analisis Data}

Data masing-masing variabel daya insktisida yang dihasilkan diolah dengan menggunakan teknik analisis probit menurut Busvine-Nash (Basvine, 1971) yang dikembangkan oleh Suripto et al. (2017)) untuk menentukan $\mathrm{LC}_{50}$ daya larvasida dan $\mathrm{EC}_{50}$ daya ovisida, daya anti feedan dan daya tolak ovipositor masing-masing fraksi ekstrak daun S. sesban terhadap P. xylostella.

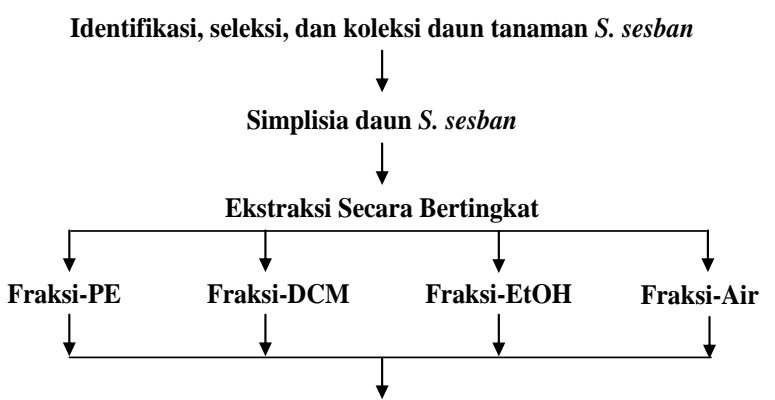

Uji pendahuluan untuk menentukan konsentrasi aplikasi dan pemeriksaan golongan senyawa aktif anti serangga
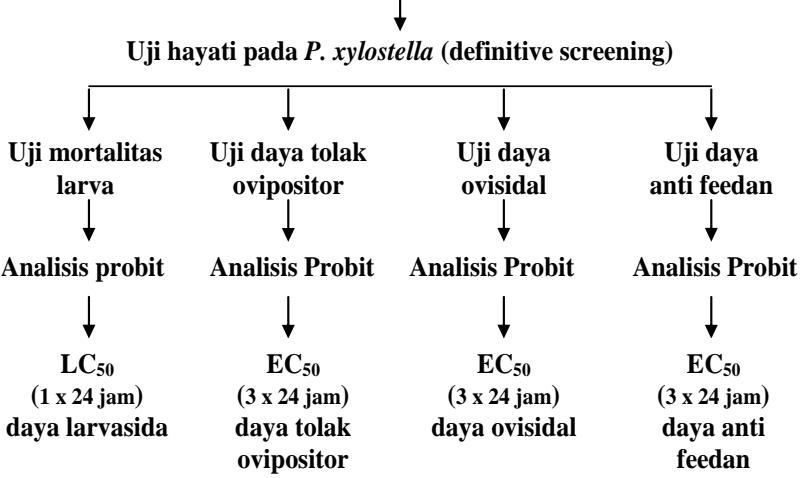

Gambar 2. Bagan alir kerja uji hayati anti serangga dari tanaman S. sesban terhadap P. xylostella.

\section{Hasil dan Pembahasan}

Pemeriksaan Bioaktif Anti Serangga Daun S. sesban

Telah dikemukakan, bahwa kandungan aktif anti serangga dari $S$. sesban adalah golongan saponin triterpen (Hamburger \& Hostettmann, 2011; Francis et al., 2012; Mahato \& Nandy, 2011).

Suripto et al. (2017) menambahkan, bahwa dari empat fraksi ekstrak daun $S$. sesban yang diperiksa, hanya fraksi ekstrak-etanol yang memiliki kandungan saponin sangat tinggi. Pada pengocokan larutan fraksi ekstraketanol daun $S$. sesban dalam tabung reaksi, terjadi pembentukan busa yang mantap (tinggi busa dalam tabung lebih dari $3 \mathrm{~cm}$ ) walaupun setelah ditetesi $\mathrm{HCl}$ $10 \%$. Pada fraksi-fraksi ekstrak lainnya, tinggi busa yang terbentuk kurang dari $1 \mathrm{~cm}$, dan berkurang lagi setelah ditetesi $\mathrm{HCl} 10 \%$.

Hasil pemeriksaan kandungan saponin S. sesban ini ditunjang dengan hasil kromatografi lapis tipis (KLT). Pada KLT dengan pengembang heksan-EtOas (1:1), kromatogram memperlihatkan adanya bercak berwarna kuning dan coklat yang relatif paling jelas pada sampel dari fraksi ekstrak-etanol, dibanding fraksi-fraksi ekstrak lainnya. 
Kinerja Anti Serangga dari Tanaman Jayanti $(S$. Sesban) terhadap P. xylostella

Berdasarkan hasil-hasil pemeriksaan kandungan bioaktif anti serangga dari daun S. sesban, maka kajian dan evaluasi anti serangga ini selanjutnya lebih banyak ditujukan terhadap fraksi ekstrak-etanol yang memiliki kandungan saponin tinggi dan fraksi ekstrak-air yang memiliki kandungan saponin sangat rendah sebagai pembanding. Secara keseluruhan, kinerja anti serangga yang meliputi daya larvasida, daya tolak ovipositor, daya hambat penetasan telur, dan daya anti feedant fraksi ekstrak-etanol daun S. sesban jauh lebih tinggi dibanding fraksi-fraksi ekstrak-air (Tabel 1 dan 2).

Tabel 1. Daya anti serangga dari fraksi ekstrak-air dan fraksi ekstrak-etanol daun S. sesban terhadap P. xylostella.

\begin{tabular}{|c|c|c|c|c|}
\hline \multirow{2}{*}{$\begin{array}{l}\text { Konsentrasi } \\
\text { Tertinggi } \\
\text { Aplikasi } \\
\text { Fraksi } \\
\text { Ekstrak- } \\
\text { Daun } S . \\
\text { sesban }\end{array}$} & \multicolumn{4}{|c|}{ Daya Maksimal Anti Serangga } \\
\hline & $\begin{array}{l}\text { Mortalitas } \\
\text { Larva }\end{array}$ & $\begin{array}{l}\text { Gagal } \\
\text { oviposisi }\end{array}$ & $\begin{array}{l}\text { Anti } \\
\text { Feedant }\end{array}$ & $\begin{array}{l}\text { Gagal } \\
\text { Tetas } \\
\text { Telur }\end{array}$ \\
\hline $\begin{array}{l}1000 \mathrm{ppm} \\
\text { Fraksi-air }\end{array}$ & $46.67 \%$ & $56,67 \%$ & $66.67 \%$ & $49.17 \%$ \\
\hline $\begin{array}{l}30 \text { ppm } \\
\text { Fraksi- } \\
\text { etanol }\end{array}$ & $50.00 \%$ & $85.00 \%$ & $78.06 \%$ & $37.18 \%$ \\
\hline
\end{tabular}

Melalui uji mode aksi larvasida, diketahui bahwa fraksi ekstrak-etanol daun $S$. sesban dengan konsentrasi $40.89 \mathrm{ppm}$ secara nyata dapat mematikan $50 \% \quad\left(\mathrm{LC}_{50}\right)$ larva $P$. xylostella. Namun demikian, dari hasil penelitian sebelumnya diketahui, bahwa aplikasi fraksi ekstraketanol daun $S$. sesban juga secara nyata dapat mematikan $50 \%$ populasi imago D. semiclausum, yang merupakan musuh alami (parasitoid) dari $P$. xylostella) dengan konsentrasi 37.38 ppm (LC L0 ) (Suripto et al., 2017).

Berdasarkan data-data penelitian tersebut diatas, maka aplikasi insektisida $S$. sesban untuk pengendalian $P$. xylostella memalui mode aksi larvasida dapat dinilai tidak selektif. Hal ini karena $\mathrm{LC}_{50}$ terhadap larva P. xylostella (serangga hama atau target pengendalian) lebih besar daripada $\mathrm{LC}_{50}$ terhadap imago D. semiclausum (musuh alami atau serangga non-target, dalam hal ini merupakan parasitoid terhadap larva P. xylostella). Dengan demikian, studi aplikasi ekstrak daun S. sesban ini lebih lanjut dilakukan selain terhadap mode aksi karvasida juga terhadap mode-mode aksi anti serangga yang lainnya, yaitu, daya tolak ovipositor, daya hambat penetasan telur, dan daya anti feedant terhadap P. xylostella.
Tabel 2. Ringkasan hasil analisis probit daya insektisida dari fraksi ekstrak-air dan fraksi ekstrak-etanol daun $S$. sesban terhadap P. xylostella.

\begin{tabular}{lll}
\hline $\begin{array}{l}\text { Variabel Daya } \\
\text { Anti Serangga }\end{array}$ & $\begin{array}{l}\text { Fraksi Ekstrak- } \\
\text { Air }\end{array}$ & $\begin{array}{l}\text { Fraksi Ekstrak- } \\
\text { Etanol }\end{array}$ \\
\hline $\begin{array}{l}\text { LC50 Toksik Letal } \\
\text { Larva }\end{array}$ & $1059.64 \mathrm{ppm}$ & $40.89 \mathrm{ppm}$ \\
$\begin{array}{l}\text { EC } 50 \text { Tolak } \\
\text { Ovipositor }\end{array}$ & $767.11 \mathrm{ppm}$ & $20.52 \mathrm{ppm}$ \\
EC $_{50}$ Anti feedant & $747.83 \mathrm{ppm}$ & $26.77 \mathrm{ppm}$ \\
$\begin{array}{l}\text { LC } \\
\text { Tetas Telur }\end{array}$ & $1235.61 \mathrm{ppm}$ & $48.24 \mathrm{ppm}$ \\
\hline
\end{tabular}

\section{Daya larvasida}

Dari empat fraksi ekstrak daun jayanti (S. sesban) yang dihasilkan, hanya fraksi ekstrak-etanol yang secara nyata berpengaruh toksik letal terhadap larva $P$. xylostella. Fraksi ekstrak-petroleum eter sampai dengan konsentrasi $350 \mathrm{ppm}$ dan fraksi ekstrak-diklorometan sampai dengan konsentrasi $150 \mathrm{ppm}$ masing-masing tidak menyebabkan kematian pada larva $P$. xylostella. Fraksi ekstrak-air daun jayanti sebenarnya dapat juga mematikan larva $P$. xylostella namun dengan konsentrasi yang sangat tinggi, jauh di atas $100 \mathrm{ppm}$. Mortalitas (prosentase jumlah individu yang mati) larva $P$. xylostella pada perlakuan fraksi ekstrak-air dan fraksi ekstrak-etanol daun S. sesban dapat dilihat pada Gambar 3 dan 4.

Berdasarkan hasil analasis probit diketahui, bahwa toksisitas akut letal terhadap P. xylostella dari fraksi ekstrak-etanol daun $S$. sesban jauh lebih tinggi daripada fraksi ekstrak-air (harga $\mathrm{LC}_{50}$ fraksi ekstrak-etanol jauh lebih rendah, yaitu 40,89 ppm bila dibandingkan dengan $\mathrm{LC}_{50}$ fraksi ekstrak-air, yaitu 1059,64 ppm.

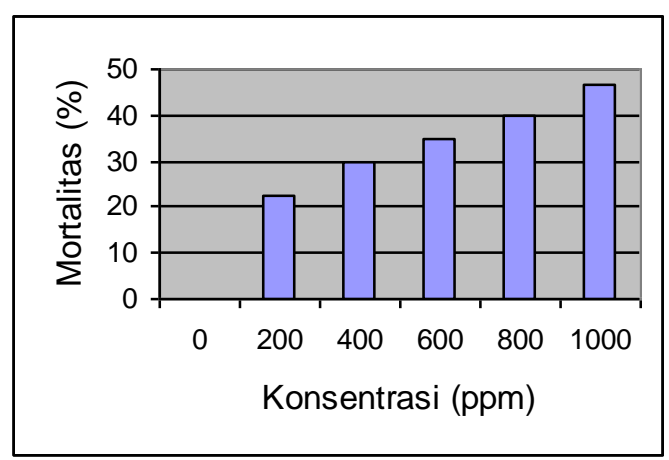

Gambar 3. Mortalitas larva $P$. xylostella pada perlakuan fraksi ekstrak-air daun $S$. sesban 


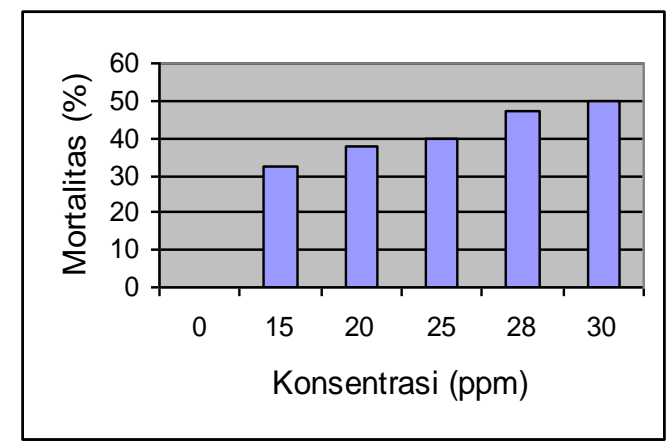

Gambar 4. Mortalitas larva P. xylostella pada perlakuan fraksi ekstrak-etanol daun $S$. sesban

Bahan aktif berupa golongan saponin dari ekstrak daun $S$. sesban dapat mempengaruhi permeabilitas membran sel, termasuk sel-sel saraf pada larva $P$. xylostella yang diberi perlakuan ekstrak tersebut. Menurut Francis et al. (2012) dan Samsuddin (2018), perubahan permeabilitas membran sel saraf dapat mengganggu transmisi sel saraf, dan sebagai salah satu dampaknya adalah terjadinya pemindahan asetilkolis terlalu cepat. Akumulasi asetilkolin yang luar biasa ini menyebabkan kejang otot secara cepat diikuti dengan pembengkakan, kelumpuhan dan akhirnya menyebabkan kematian larva.

Telah dikemukakan, bahwa $\mathrm{LC}_{50}$ fraksi ekstraketanol daun S. sesban terhadap larva P. xylostella (sebagai serangga target) adalah $40.89 \mathrm{ppm}$. Harga ini lebih besar dari pada $\mathrm{LC}_{50}$ fraksi ekstrak-etanol daun $S$. sesban tersebut terhadap $D$. semiclausum, yaitu $37.38 \mathrm{ppm}$. $D$. semiclausum merupakan musuh alami, dalam hal ini parasitoid terhadap larva instar III dari P. xylostella (Suripto et al., 2017). Karena harga $\mathrm{LC}_{50}$ terhadap larva $P$. xylostella lebih besar daripada $\mathrm{LC}_{50}$ terhadap musuh alaminya, D. semiclausum, maka aplikasi fraksi ekstraketanol daun $S$. sesban untuk pengendalian $P$. xylostella dinyatakan tidak selektif bila target pengendalian tersebut diarahkan terhadap fase larva.

\section{Daya tolak ovipositor}

Terserangnya tanaman kubis oleh ulat kubis $(P$. xylostella) selain karena disukainya daun kubis oleh fase larva, juga karena daun kubis memiliki kombinasi senyawa yang dapat menarik (attractant) serangga betina untuk meletakkan telurnya (Solichah et al., 2014). Ekstrak daun jayanti (S. sesban), dalam hal ini fraksi ekstraketanol juga nyata mempunyai daya tolak terhadap kedatangan imago $P$. xylostella betina untuk meletakkan telurnya (oviposisi) pada tanaman kubis.

Daya tolak oviposisi dari fraksi ekstrak-etanol daun S. sesban ini semakin besar dengan meningkatnya konsentrasi perlakuan. Fraksi ekstrak-air daun jayanti juga memiliki daya tolak terhadap oviposisi $P$. xylostella namun dengan konsentrasi yang jauh lebih tinggi dari pada fraksi ekstrak-etanol. Presentase penghambatan oviposisi P. xylostella oleh perlakuan fraksi ekstrak-air dan fraksi ekstrak-etanol daun $S$. sesban dapat dilihat pada Gambar 5 dan 6.

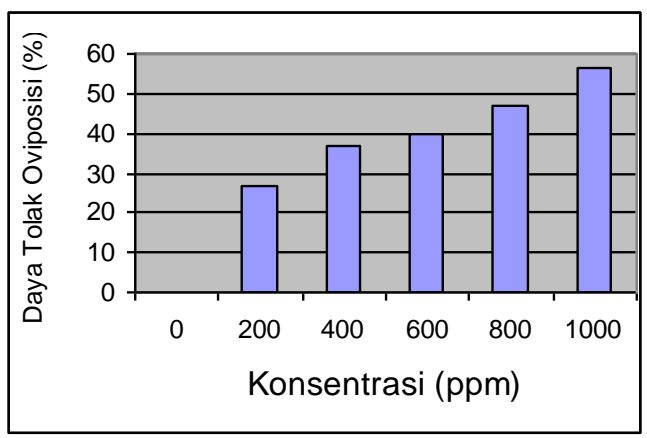

Gambar 5. Presentase penghambatan oviposisi P. xylostella pada perlakuan fraksi ekstrak-air daun $S$. sesban.

Berdasarkan analisis probit diketahui, bahwa konsentrasi efektif $\left(\mathrm{EC}_{50}\right)$ untuk menolak $50 \%$ oviposisi P. xylostella dari fraksi ekstrak-etanol adalah 20,52 ppm. Harga $\mathrm{EC}_{50}$ terhadap ovipostitor ini lebih kecil daripada harga $\mathrm{LC}_{50}$ terhadap $D$. semiclausum sebagai serangga non-target. Dengan demikian, maka aplikasi fraksi ekstrak-etanol daun $S$. sesban memilik selektivitas anti serangga yang tinggi (selektif) untuk pengendalian $P$. xylostella, bila sasaran pengendalian diarahkan untuk menolak kedatangan ovipositor.

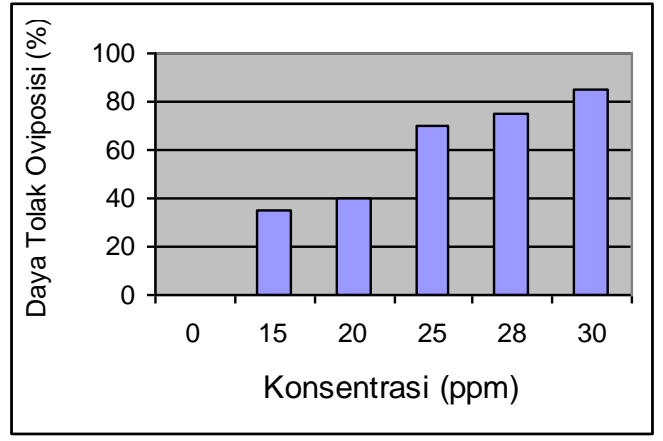

Gambar 6. Presentase penghambatan oviposisi P. xylostella pada perlakuan fraksi ekstrak-etanol daun $S$. sesban

Oviposisi $P$. xylostella pada tanaman kubis didorong oleh adanya senyawa glukosionat, yaitu 1isotiosianat-3-(metilsulfini)-propana dan 1-isotiosianat-4(metilsulfini)-butana. Kandungan ini mempengaruhi kualitas rangsang khusus daun kubis yang menentukan urutan ketertarikan oviposisi (Payal \& Vikram, 2010; Solichah et al., 2014).

Dengan penggunaan ekstrak daun $S$. sesban yang melapisi permukaan daun kubis mungkin dapat menggagalkan fungsi rangsang khusus atraktan pada daun kubis tersebut. Dengan demikian, maka perlindungan 
tanaman kubis dengan penyemprotan ekstrak daun $S$. seban pada permukaan tanaman kubis dapat mereduksi daya tarik tanaman kubis terhadap kedatangan dan oviposisi $P$. xylostella, dan hal ini dapat dipandang sebagai pengendalian yang selektif secara ekologis dan aman.

\section{Daya anti feedant}

Daya antifeedant dari ekstrak daun jayanti ditunjukkan dengan prosentase penurunan bobot relatif terhadap control dari daun kubis yang dimakan oleh larva $P$. xylostella. Daya antifeedan dari fraksi ekstrak-etanol daun $S$. sesban ini semakin besar dengan meningkatnya konsentrasi perlakuan. Fraksi ekstrak-air daun jayanti juga memiliki daya antifeedan terhadap $P$. xylostella namun dengan konsentrasi yang jauh lebih tinggi dari pada fraksi ekstrak-etanol. Daya anti feedan dari fraksi ekstrak-air dan fraksi ekstrak-etanol daun $S$. sesban terhadap larva $P$. xylostella dapat dilihat pada Gambar 7 dan 8 .

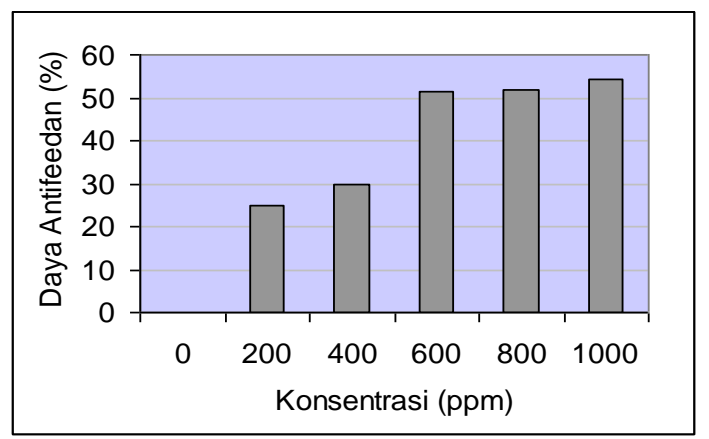

Gambar 7. Daya antifeedan fraksi ekstrak-air daun S. sesban terhadap larva $P$. xylostella

Berdasarkan analisis probit diketahui, bahwa konsentrasi efektif 50\% berdaya anti feedant terhadap $P$. xylostella $\left(\mathrm{EC}_{50}\right)$ dari fraksi ekstrak-etanol daun S. sesban adalah $26,77 \mathrm{ppm}$, sedangkan $\mathrm{EC}_{50}$ dari fraksi ekstrak-air daun tanaman tersebut adalah 747,83 ppm.

Kandungan saponin ekstrak dari daun $S$. sesban yang diberikan pada permukaan daun kubis dapat menghilangkan pengaruh atraktan daun kubis untuk dimakan oleh larva $P$. xylostella. Di samping itu, secara umum senyawa saponin dapat menghambat transmisi sel sarap yang berperan dalam aktivitas makan. Kandungan saponin dari ekstrak daun $S$. sesban ini juga nyata menunjukkan daya tolak makan terhadap larva $P$. xylostella pada daun tanaman kubis. Hal ini mendukung pendapat Syamsuddin (2018), golongan senyawa saponin triterpen dapat menghambat aktivitas makan dari larva $P$. xylostella.

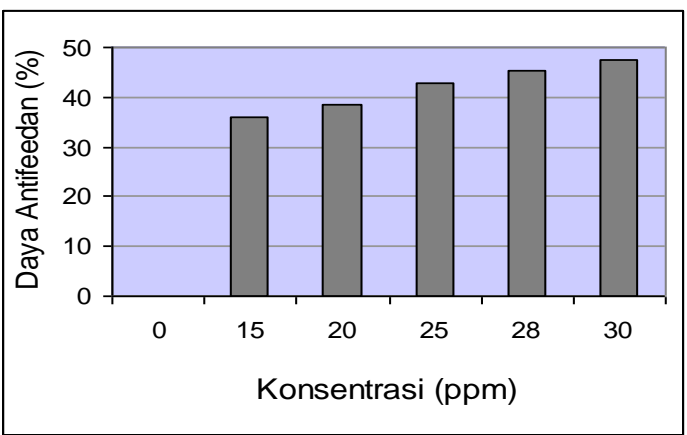

Gambar 8. Daya antifeedan fraksi ekstrak-etanol daun $S$. sesban terhadap larva P. xylostella

Berdasarkan analisis probit diketahui, bahwa konsentrasi efektif $50 \%$ berdaya antifeedan terhadap $P$. xylostella $\left(\mathrm{EC}_{50}\right)$ dari fraksi ekstrak- etanol daun $S$. sesban adalah $26,77 \mathrm{ppm}$. Hasil ini menunjukan, bahwa aplikasi fraksi ekstrak-etanol daun $S$. sesban adalah pengendalian yang selektif sebagai anti feedan terhadap ulat kubis, $P$. xylostella.

\section{Daya hambat penetasan telur}

Fraksi ekstrak-etanol daun S. sesban juga memiliki kemampuan menghambat penetasan telur (daya vosidal) P. xylostella. Daya ovisidal dari fraksi ekstrak-etanol daun $S$. sesban ini semakin besar dengan meningkatnya konsentrasi perlakuan. Fraksi ekstrak-air daun S. sesban juga memiliki daya ovisidal terhadap $P$. xylostella namun dengan konsentrasi yang jauh lebih tinggi dari pada fraksi ekstrak-etanol. Prosentase penghambatan penetasan telur P. xylostella oleh perlakuan fraksi ekstrak-air dan fraksi ekstrak-etanol daun S. sesban dapat dilihat pada Gambar 9 dan 10.

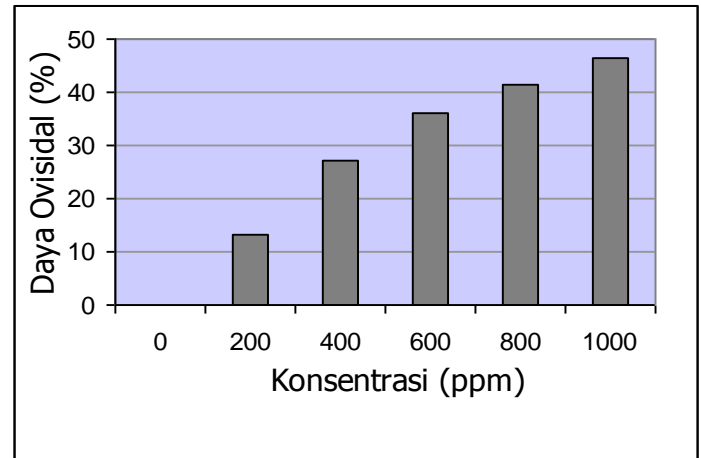

Gambar 9. Daya ovisidal fraksi ekstrak-air daun S. sesban terhadap P. xylostella

Berdasarkan analisis probit diketahui, bahwa konsentrasi efektif untuk menghambat $50 \%$ penetasan telur $P$. xylostella $\left(\mathrm{EC}_{50}\right)$ dari fraksi ekstrak- etanol daun S. sesban adalah $48,24 \mathrm{ppm}$, sedangkan $\mathrm{EC}_{50}$ dari fraksi ekstrak-air daun tanaman tersebut adalah 1235,61 ppm. 


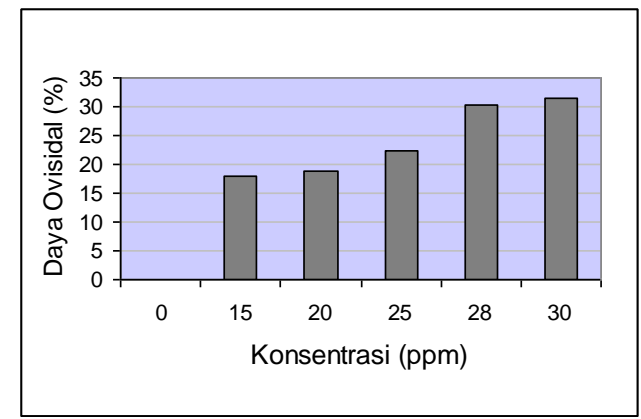

Gambar 10. Daya ovisidal fraksi ekstrak-etanol daun $S$. sesban terhadap P. xylostella

Stadia telur dari beberapa jenis serangga sangat rentan terhadap bahan asing yang memiliki tegangan permukaan tinggi, seperti senyawa-senyawa saponin, yang dapat menghambat pertumbuhan embrio akibat kerusakan khorion (Quetin-Leclerq et al., 2012). Kehadiran saponin dari ekstrak daun $S$. sesban mungkin dapat merusak khorion telur $P$. xylostella. Hal ini mendukung hasil pengamatan yang pernah dilakukan oleh Payal \& Vikram (2010) dan Anil et al. (2013), yaitu bahwa kerusakan khorion telur serangga menyebabkan pertumbuhan embrio terganggu karena terdedah dengan lingkungan suhu, kelembaban, tekanan, dan zat-zat asing di luar telur.

\section{Kesimpulan}

Dari empat fraksi ekstrak daun $S$. sesban yang dihasilkan, fraksi ekstrak-etanol memiliki daya anti serangga terhadap $P$. xylostella paling tinggi. Aplikasi insektisida $S$. sesban untuk pengendalian $P$. xylostella dengan mode aksi anti feedant dan anti ovipositor masing-masing adalah seletif, karena konsentrasi aplikasi efektifnya lebih kecil daripada konsentrasi yang dapat mematikan D. semiclausum. Aplikasi insektisida $S$. sesban dengan mode aksi larvasida dan ovisida masingmasing adalah tidak seletif, karena konsentrasi aplikasi efektinya lebih besar daripada konsentrasi yang dapat mematikan D. semiclausum.

Penggunaan bahan insektisida dari S. sesban untuk pengendalian $P$. xylostella hendaknya diarahkan untuk aplikasi menolak oviposisi dan menghambat aktivitas makan, dan tidak disarankan untuk aplikasi mematikan larva dan menghambat penetasan telur $P$. xylostella karena memerlukan konsentrasi aplikasi yang lebih besar dan dapat menekan populasi D. semiclausum.

Selektivitas antiseranga secara ekologis dan efektivitas penggunaan bahan insektisida dari S. sesban untuk pengendalian $P$. xylostella perlu dievaluasi dengan mempelajari lebih lanjut stabilitas bahan aktif anti serangga dari $S$. sesban selama penyimpanan serbuk kering daun sebelum diekstraksi, penyimpanan ekstrak sebelum diaplikasikan, dan stabilitasnya selama aplikasi.

\section{Ucapan terima kasih}

Penelitian ini didukung penuh dan didanai oleh Kementerian Riset, Teknologi, dan Pendidikan Tinggi, Republik Indonesia melalui Lembaga Penelitian dan Pengabdian kepada Masyarakat dan Fakultas Matematika dan Ilmu Pengetahuan Alam, Universitas Mataram.

Juga terima kasih diberikan kepada mahasiswa Ilmu Lingkungan di Program Studi Biologi Fakultas Matematika dan Ilmu Pengetahuan Alam, Universitas Mataram, tahun akademik 2019/2020

\section{Daftar Pustaka}

Anil, U. T., Payal, R. D., Rakesh,E. M. \& Sanjay, J. S. (2013). Effect of saponins from Sesbania sesban L. (Merr.) on acute and chronic inflammation in experimental induced animals. Journal of Biological Sciences, 13: 123-130. DOI: $\underline{10.3923 / \mathrm{jbs} .2013 .123 .130}$

Busvine, J.R. (1971). A Critical Review of The techniques for Testing Insecticides.

Commonwealth Agricultural Bureaux, London. Pp 264-276. https://www.cabdirect.org/cabdirect /A critical review of the techniques for testing insecticides. 2nd Edition/19712902437

Clesceri, L.S., Greenberg, A.E. \& R.R Trussel (1989). Standard Methods for Examination of Water and Wastewater. APHA. New York, Washington DC. Bookmark. https://trove.nla.gov.au/work/16646325

Francis, G., Kerem, Z., Makkar, H.P.S. \& Becker, K. (2012). The biological action of saponins in animals system: a review. British Journal of Nutrition. $\quad 88$ : 587-605. DOI: $\underline{10.1079 / B J N 2002725}$

Hamburger, M. \& K. Hostettmann (2011). Bioactivity in plants: The link between phytochemistry and medicine phytochemistry. Phytochemistry. 30 (12):3864-3874.

https://www.sciencedirect.com/journal/phytoche mistry

Mahato, S.B. \& A.K. Nandy (2011). Triterpenoid saponins discovered between 1987 and 1989. Phytochemistry. $30 \quad$ (5):1357-1390. DOI: 10.1016/0031-9422(91)84170-w 
Payal, R. D. \& Vikram, S. (2010). Evaluation of crude saponins extract from leaves of Sesbania sesban (L.) Merr. for topical anti-inflammatory activity. Int. J. Res. Pharm. Sci. 1 (3): 296-299. https://www.ijrps.pharmascope.org

Quetin-Leclerq, J., Elias, R. \& G. Balansard (2012). Cytotoxic activity of some triterpenoid saponins. Planta Med. 58:279-281. PMID: 1409985/DOI: $\underline{10.1055 / \mathrm{s}-2006-961456}$

Samsuddin (2018). Pengendalian Hama dengan Insektisida Alami. Agrotekma: Jurnal Agroteknologi dan Ilmu Pertanian. 4 (1): 11-20. DOI: $\quad 10.31289 /$ agr.v4i1.2713/ http://en www.Pertanian sehat.org.id/ Diakses 25 Desember 2018.

Solichah, C., Witjaksono \& Martono, E. (2014). Ketertarikan Plutella xylostella L. Terhaap beberapa macam ekstrak daun Cruciferae. Agrosains 6(2): $80-84$.

DOI:10.21082/bullittro.v27n2.2016.174-180

Suripto, Sukiman \& Gunawan, E.R. (2017). Insecticidal selectivity of jayanti plant (Sesbania sesban) for integrated control of diamondback moth (Plutella xylostella). Asian Journal of Agriculture. 1(2):8084. https://doi.org/10.13057/asianjagric/g010205

Talekar, N. S., Yang, J. C. \& Lee, S. T. (2018). Introduction of Diadegma semiclausum to contoll diamondback moth in Taiwan.

https://agris.fao.org/agrissearch/search.do?recordID=US201301766495

Wang, Xin-geng, Duff, J., Keller, M., Zalucki, M.P., Liu,Shu-sheng \& Bailey, P. (2014). Role of Diadegma semiclausum (Hymenoptera: Ichneumonidae) in controlling Plutella xylostella (Lepidoptera: Plutellidae): Code exclusion experiments and direct observation. Biocontrol Science and Technology. 14: 571 - 586. https://doi.org/10.1080/09583150410001682304

Wang, Xin-geng, Duff. \& Keller, A. (2018). Patch time allocation by the parasitoid Diadegma semiclausum (Hymenoptera: Ichneumonidae) Effect of interpatch distance. Journal of Insect Behavior. 16: 279-293(2003) 